Annals of Glaciology $5 \quad 1984$

(c) International Glaciological Society

\title{
FLOW BEHAVIOR OF BASAL ICE AS RELATED TO
}

\author{
MODELING CONSIDERATIONS
}

\author{
by \\ Hitoshi Shoji and Chester C. Langway Jr. \\ (Ice Core Laboratory, Department of Geological Sciences, State University of New York at \\ Buffalo, 4240 Ridge Lea Road, Amherst, New York 14226, U.S.A.)
}

\begin{abstract}
Simple shear tests on the bottom $17 \mathrm{~m}$ of basal ice from Camp Century, Greenland, were carried out in order to study the flow behavior near the bottom of an ice sheet and its implications for ice-sheet modeling. The ice core was recovered in 1966. Our experimental results show that the basal ice tested, (which contained alternating bands of dirty and clean ice) has the highest strain-rate ever reported for polycrystalline ice under simple shear. The enhancement factors obtained are interpreted in terms of fabric, ageing, and impurity. Horizontal velocity profiles are calculated using data reported previously for Camp Century and Dye 3 stations. Various depthage relationships are compared with these data. The higher than expected shear strain-rates measured on samples of near-bottom ice from Camp Century may very well exist at other locations. If such high shear strain-rates are more prevalent than presently thought, they could have an important bearing on ages calculated by physical or mathematical models of ice sheets.
\end{abstract}

\section{INTRODUCTION}

Mechanical tests on basal ice samples from the Camp Century $\left(77^{\circ} 10^{\prime} \mathrm{N}, 61^{\circ} 08^{\prime} \mathrm{W}\right)$ ice core, recovered in 1966, were carried out in order to study the flow behavior near the bottom of the ice sheet as related to ice-flow modeling. The relationship between strainrate and stress with laboratory-prepared randomly oriented polycrystalline ice is well described by Glen's law (Glen 1955, Barnes and others 1971). For natural glacier ice three additional factors should be considered which enhance strain-rate: (1) fabrics (Lile 1978, Russel1-Head and Budd 1979), (2) impurities (Jones and Glen 1969, Nakamura and Jones 1973), and (3) debris particles (Hooke and others 1972).

In 1966 a continuous ice core was recovered at Camp Century from the ice-sheet surface to the bottom at a depth of $1387 \mathrm{~m}$ (Hansen and Langway 1966). Physical and chemical properties were analysed by Herron [S L] and Langway $(1979,1982)$ and Herron [M M] and Langway (1982) respectively. The bottom $17 \mathrm{~m}$ of this vertical ice core contains a debrisladen zone. At Camp Century the surface velocity was measured to be $3.3 \mathrm{~m} \mathrm{a}^{-1}$ with a surface slope of $3.5 \times 10^{-3}$ rad (Mock 1968). The temperature in the bore hole varied from $-24^{\circ} \mathrm{C}$ at the surface to $-13^{\circ} \mathrm{C}$ at the bottom, with a minimum value of $-24.7^{\circ} \mathrm{C}$ at about $200 \mathrm{~m}$ depth (B L Hansen private communication).

A depth-age relationship (time scale 1) was calculated for Camp Century by Dansgard and Johnsen
(1969) and by Hammer and others (1978) based on the $\delta^{180}$ (Dansgaard and others 1969) and microparticle (Hammer 1977[a], [b]) profiles. These data yielded an accumulation rate of $0.382 \mathrm{~m} \mathrm{a}^{-1}$ at the surface, and a vertical strain-rate that has a constant value of $3.32 \times 10^{-4} \mathrm{a}^{-1}$ from the surface to a distance of $429 \mathrm{~m}$ from the bottom, and then decreases linearly to the bottom.

Dansgaard and others (1982) compared the published Camp Century $\delta^{18} 0$ profile (Dansgaard and others 1969) with the published Dye $3 \delta^{18} 0$ profile (Dansgaard and Reeh 1982) and the deep-sea foraminifera record (Hays and others 1976), and obtained another time scale (time scale 2) for the Camp Century ice core. Time scale 2 gives much older ages for the bottom $250 \mathrm{~m}$ than time scale 1.

\section{EXPERIMENTAL PROCEDURE}

\section{2(a). Specimen preparation}

Three samples were seTected from the Camp Century basal ice core for these tests, a "dark" sample (type 1 from 1375 m depth), an "intermediate" (or "medium") sample (type 2 from $1377 \mathrm{~m}$ ) and a "clear" sample (type 3 from $1379 \mathrm{~m}$ ). The sample classification is based on visual observations of transmitted white light through the ice core using a light table (Herron [S L] and Langway 1979). Each sample was more than $30 \mathrm{~cm}$ long and was cut into several specimens for microscopic observations (M) and simple shear tests $(S)$. Samples were rough-cut with a bandsaw and the surface finished with a microtome to about $1 \times 3 \times 10 \mathrm{~cm}$ (for M) and $(21.4 \pm 0.05) \times(22.4 \pm 0.2)$ $x(31.4 \pm 0.4) \mathrm{mm}$ (for S). Vertical and horizontal specimens (M) were prepared for observations of microstructure. Specimens for simple shear tests $(S)$ were prepared so as to have the applied shear stress plane parallel to the horizontal plane of each icecore sample. An additional specimen of type 2 was prepared so that the applied shear stress plane was inclined $45^{\circ}$ from the horizontal plane so that the fabric enhancement factor could be examined.

2(b). Optical microscopic observation

Grain size was measured by the intercept method (Herron [S L] and others 1982) under an optical microscope. Internal microstructure was observed and photographed for gas, liquid and solid inclusions. Evaporation pits were formed on the specimen surface by the formvar method (Higuchi 1958, Matsuda 1979) to determine the crystal orientations.

2(c). Simple shear tests

The simple shear creep testing apparatus was 
specially designed and constructed for this study. It was also used for the mechanical tests made on the fresh ice-core samples from the Dye 3 ice core very soon after recovery (Shoji and Langway 1982[b]). The two side faces of the specimen were frozen onto brass plates so as to have a thickness of $31.4 \mathrm{~mm}$. One of the plates was fixed to the frame of the apparatus whilst the other was allowed to slide vertically with a linear motion using vertical rods driven by a controlled weight. The vertical displacement of the sliding plate was recorded with a 1 inear voltage differential transformer (LVDT) detector. The apparatus was contained in a temperature-controlled insulated box in a laboratory cold room kept at $-15^{\circ} \mathrm{C}$. Temperature was measured with copper-constantan thermocouples and maintained at $-13^{\circ} \mathrm{C}$ to conform with the measured value at the bottom of the Camp Century bore hole. The temperature fluctuation was with in $0.2^{\circ} \mathrm{C}$ for each test run.

3. EXPERIMENTAL RESULTS AND DISCUSSIONS 3(a). Optical microscope observations

The general characteristics of the types of basal ice relevant to the present study are given in Table I (Herron [S L] and Langway 1979). Descriptions of the three samples tested are given in Table II. Changes in physical properties of an ice core with time after core recovery were earlier reported using the pressure change with time of an air-bubble
(Langway 1958). This is essentially an ice deformation process centered around air bubbles and driven by a hydrostatic pressure difference between the gas in the air bubble and the ambient pressure (Shoji and Langway 1983). The internal surfaces of air bubbles in basal ice samples (types 1,2 and 3) were observed to be very smooth compared with those of bubbles in fresh ice core (Shoji and Langway 1982[a]). This suggests that the air pressure in the gas bubbles may already be very close to ambient pressure and that the ice deformation around the air bubbles is no longer active. With the type 1 sample (dark ice), a significant decrease in color intensity was observed near the edges of the ice core. This is probably related to a process of diffusion from the center of the included impurities in the core outwards. Grain-size distribution from the center of the cross-section of the core to the periphery also revealed a large increase in grain size from $0.5 \mathrm{~mm}$ at the center to 3 to $4 \mathrm{~mm}$ near the periphery. This change in grain size is observed in specimens from both horizontal and vertical sections (Fig.1). The triple junctions of grain boundaries are mostly decorated with small-sized debris particles as shown in Figure 2(a), which clearly identify the location of grain boundaries in three dimensions. Within large ice grains near the outer core surface, chain networks of air bubbles were of ten observed with a comparable network size $(0.5 \mathrm{~mm})$ to grain size near the center of the core (Fig.2(b)). Because of

\section{TABLE I. GENERAL CHARACTERISTICS OF BASAL ICE (CAMP CENTURY)}

\begin{tabular}{lcccc}
$\begin{array}{c}\text { Color } \\
\text { appearance }\end{array}$ & $\begin{array}{c}\text { Debris } \\
\text { concentration }\end{array}$ & $\begin{array}{c}\text { Total gas } \\
\text { content }\end{array}$ & $\begin{array}{c}\text { Density at } \\
-13^{\circ} \mathrm{C}\end{array}$ & $\begin{array}{c}\text { Percentage of } \\
\text { ice type in } 17 \mathrm{~m} \\
\text { of basal ice }\end{array}$ \\
\hline & wt \% & $\mathrm{m}^{3} \mathrm{~kg}^{-1}(\mathrm{STP})$ & $\mathrm{kg} \mathrm{m}^{-3}$ & $\%$ \\
Clear & 0.02 & $(5.3 \pm 1.1) \times 10^{-5}$ & $914 \pm 1$ & 10 \\
Light & 0.15 & $(5.3 \pm 1.1) \times 10^{-5}$ & $914 \pm 1$ & 35 \\
Medium & 0.31 & $(5.3 \pm 1.1) \times 10^{-5}$ & $914 \pm 1$ & 53 \\
$\begin{array}{c}\text { Dark } \\
\begin{array}{c}\text { Clear ice } \\
\text { (overlying } \\
\text { basal ice }\end{array}\end{array}$ & 0.70 & $(5.3 \pm 1.1) \times 10^{-5}$ & $914 \pm 1$ & 2 \\
\hline
\end{tabular}

TABLE II. MICROSTRUCTURE OF BASAL ICE SAMPLES (CAMP CENTURY)

\begin{tabular}{|c|c|c|c|c|c|c|}
\hline $\begin{array}{c}\text { Sample } \\
\text { no. }\end{array}$ & $\begin{array}{l}\text { Color } \\
\text { appearance }\end{array}$ & $\begin{array}{l}\text { Depth } \\
\text { from the } \\
\text { surface } \\
\text { (m) }\end{array}$ & $\begin{array}{c}\text { Distance } \\
\text { from the } \\
\text { bottom } \\
\text { (m) }\end{array}$ & $\begin{array}{l}\text { Major } \\
\text { inclusions }\end{array}$ & $\begin{array}{l}\text { Minor } \\
\text { inclus ions }\end{array}$ & $\begin{array}{l}\text { First } \\
\text { quartile } \\
\text { Degrees from } \\
\text { vertical } \\
\text { direction } \\
\end{array}$ \\
\hline 1 & Dark & 1375 & 12 & $\begin{array}{l}\text { Air bubbles, } \\
\text { debris } \\
\text { particles }\end{array}$ & $\begin{array}{l}\text { Liquid } \\
\text { veins, } \\
\text { lenses }\end{array}$ & $20 \pm 3$ \\
\hline 2 & Medium & 1377 & 10 & Air bubbles & $\begin{array}{l}\text { Gas } \\
\text { hydrates, } \\
\text { debris } \\
\text { particles }\end{array}$ & $10 \pm 3$ \\
\hline 3 & $\begin{array}{l}\text { Clear to } \\
\text { light }\end{array}$ & 1379 & 8 & Air bubbles & $\begin{array}{l}\text { Gas } \\
\text { hydrates, } \\
\text { debris } \\
\text { particles }\end{array}$ & $10 \pm 3$ \\
\hline
\end{tabular}


a.

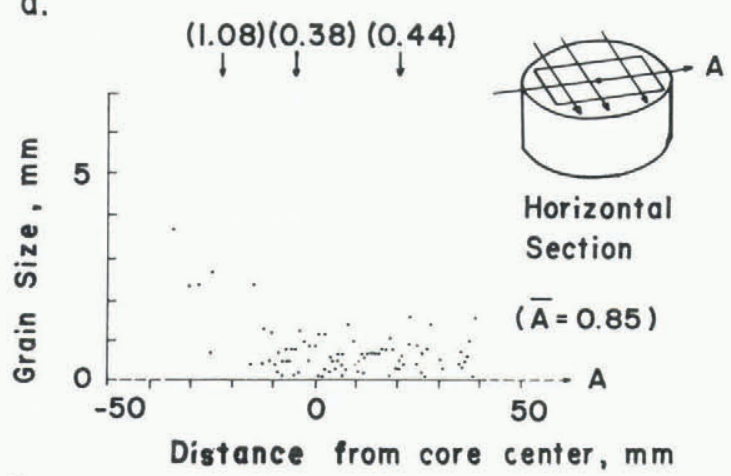

b.

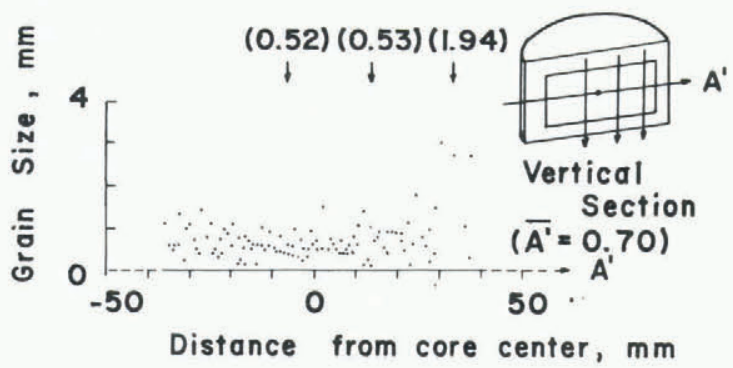

Fig.1. Grain-size distribution of type 1 sample, dark ice, with distance from ice core center. (a) horizontal section, (b) vertical section. Numerical values in parentheses are average grain sizes in $\mathrm{mm}$.
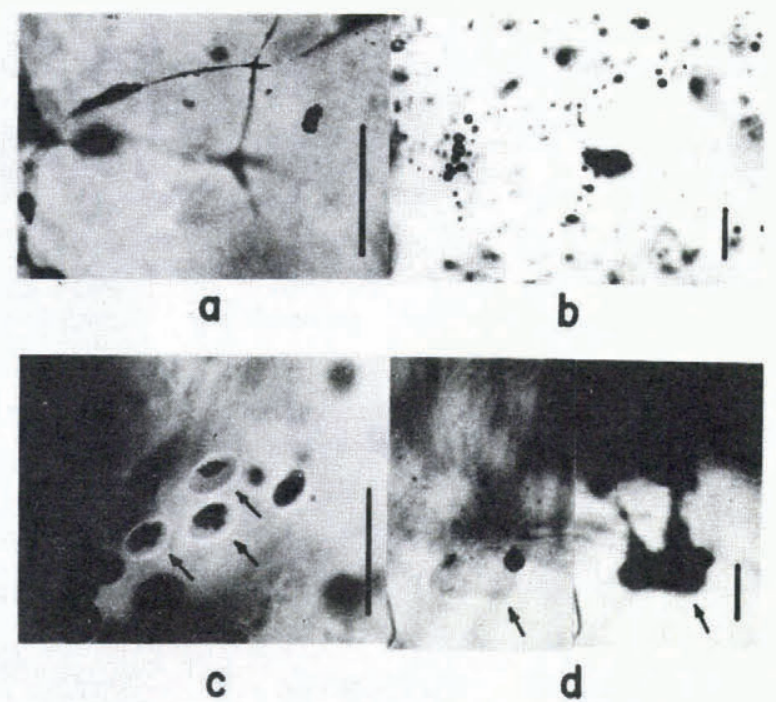

Fig.2. Microstructure of basal ice. Each vertical bar equals $0.2 \mathrm{~mm}$. (a) triple junction of grain boundaries decorated with small debris particles, (b) air-bubble chain network observed with in a large grain near the core surface, (c) liquid lenses (denoted by arrows) in a dark sample, (d) a transformation of a gas hydrate inclusion (left) into gas bubbles ( $r i g h t)$ under heat treatment. Arrows denote the same position at different times.

these alterations, specimens used for the shear tests were prepared from the non-recrystallized central part of the original ice core. Microscopic observations also revealed that liquid veins and lenses formed at the triple junctions of grain boundaries and grain boundary planes, respectively (Fig.2(c)). The size of the liquid inclusions increased when the temperature of the sample was increased. Oguro (1975) showed in his studies of the growth of single ice crystals using dilute aqueous solutions that pockets of solutions were formed when the concentration of impurity ( $\mathrm{NH}_{4} \mathrm{~F}$ or $\mathrm{NaCl}^{\text {in }} \mathrm{h}$ is studies) in the original solution exceeded $1000 \mathrm{ppm}$. These liquid inclusions observed in type 1 samples (dark ice) were generally accompanied by debris particles or aggregates of particles in suspension.

In the other two samples tested (clear ice, type 3 , and medium ice, type 2) a very small number of gas hydrate inclusions were observed which were similar to those found in the fresh ice core from Dye 3 (Shoji and Langway $1982[a])$. By using a heat treatment whereby the specimen is gradually melted under a microscope, the transformation of the gas hydrates into a large volume of individual gas bubbles, as shown in Figure 2(d), was observed. According to a phase diagram constructed by Miller (1969), an air hydrate inclusion in clathrate structure $I$ is not stable under long-term ice-core storage (at about $-30^{\circ} \mathrm{C}$ ) and atmospheric pressure. This agrees with our observations that only a small number of gas hydrate inclusions rema in for long af ter core recovery.

Results of ice-fabric analys is using the evaporation pit method are given in Table II (first quartile of c-axis verticality). 3(b). Simple shear tests

Each specimen was deformed more than $1.2 \%$ in shear-strain in order to obtain the necessary minimum creep rate (Russell-Head and Budd 1979). The results show that these ice specimens have the highest shear strain-rate ever reported for polycrystalline ice under simple shear (Fig.3). Specimens of types

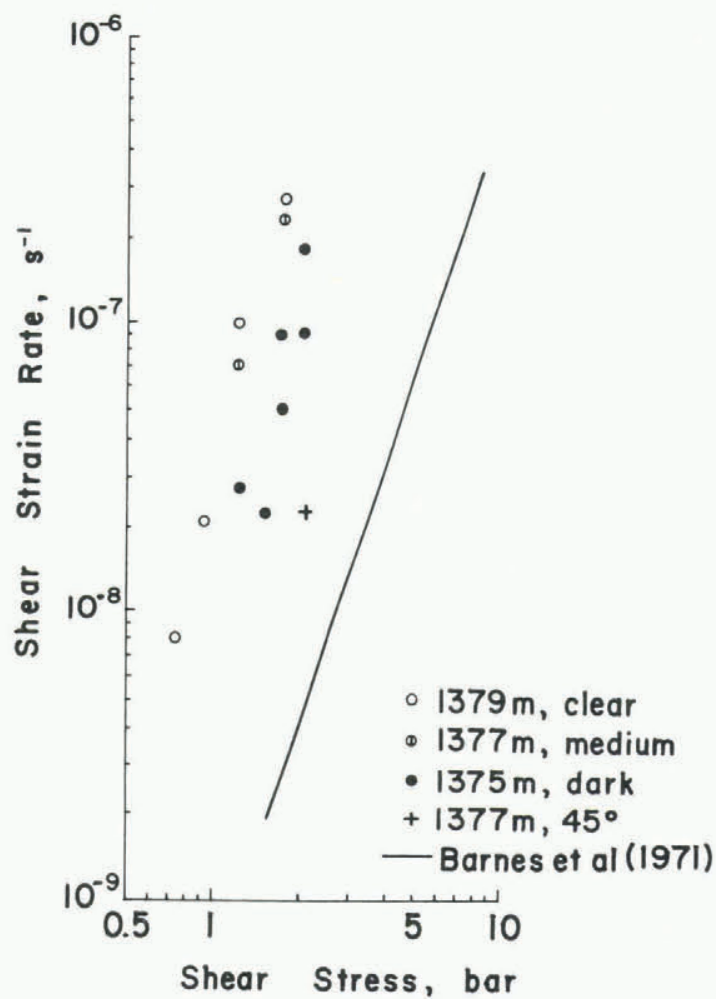

Fig.3. Logarithmic plot of shear strain-rate versus shear stress. Simple shear stress was applied along the horizontal plane of the core. Sample "1377m, $45^{\circ}$ " was tested with the applied simple shear stress inclined at $45^{\circ}$ from the vertical axis of the core. Experimental results on randomly oriented artificial polycrystalline ice by Barnes and others (1971) have been converted from uniaxial stress/strain-rate to shear stress/strain-rate using Nye's (1957) formula. All data points wére experimentally obtained at a temperature of $-13^{\circ} \mathrm{C}$. 
TABLE III. ESTIMATION OF ENHANCEMENT FACTOR

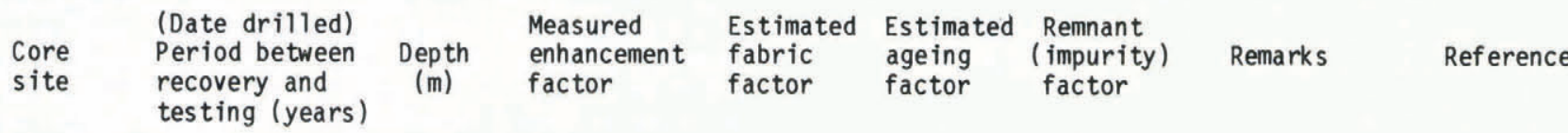
Simple shear, parallel to horizontal plane (easy glide)

\begin{tabular}{|c|c|c|c|c|c|c|c|c|}
\hline \multirow{3}{*}{$\begin{array}{l}\text { Camp } \\
\text { Century } \\
\left(77^{\circ} 10^{\prime} \mathrm{N}\right. \\
\left.61^{\circ} 08^{\prime} \mathrm{W}\right)\end{array}$} & \multirow{3}{*}{$\begin{array}{r}(1966) \\
13-17\end{array}$} & \multirow{3}{*}{$\begin{array}{l}1377-1379 \\
1375\end{array}$} & \multirow{3}{*}{$\begin{array}{l}40-100 \\
20-50\end{array}$} & \multirow{3}{*}{$\begin{array}{l}4 \\
2\end{array}$} & \multirow{3}{*}{$\begin{array}{l}4 \\
4\end{array}$} & \multirow{3}{*}{$\begin{array}{l}3-6 \\
3-6\end{array}$} & \multirow{3}{*}{$\begin{array}{l}\text { Basal ice clear } \\
\text { to medium } \\
\text { Basal, dark }\end{array}$} & \multirow{3}{*}{$\begin{array}{l}\text { Present } \\
\text { work } \\
\text { Present } \\
\text { work }\end{array}$} \\
\hline & & & & & & & & \\
\hline & & & & & & & & \\
\hline \multirow[t]{2}{*}{$\begin{array}{l}\text { Dye } 3 \\
\left(64^{\circ} 12^{\prime} N\right. \\
\left.43^{\circ} 47^{\prime} \mathrm{W}\right)\end{array}$} & $\begin{array}{l}(1980 / 81) \\
=0.1\end{array}$ & $235-1293$ & $0.5-2$ & $0.5-2$ & 1 & 1 & Holocene & $\begin{array}{l}\text { Shoji and } \\
\text { Langway } \\
(1982[\mathrm{~b}])\end{array}$ \\
\hline & & 1814 & 24 & 4 & 1 & 6 & Wiscons in & $\begin{array}{l}\text { Shoji and } \\
\text { Langway } \\
\text { (1982[b]) }\end{array}$ \\
\hline \multirow{2}{*}{$\begin{array}{l}\text { Cape } \\
\text { Folger } \\
\left(66^{\circ} \mathrm{S} 111^{\circ} \mathrm{E}\right)\end{array}$} & $\underset{<3}{(1969)}$ & 200 & 2.78 & 2.79 & 1 & 1 & Holocene & Lile (1978) \\
\hline & $\begin{array}{c}(1974) \\
\leqslant 3\end{array}$ & $55-260$ & -Simple sh & $r, 45^{\circ}$ inc & 1 & Iid & Holocene & $\begin{array}{l}\text { Russel1- } \\
\text { Head and } \\
\text { Budd (1979) }\end{array}$ \\
\hline $\begin{array}{l}\text { Cape } \\
\text { Folger }\end{array}$ & $\underset{<3}{(1969)}$ & 200 & 0.22 & 0.21 & 1 & 1 & Holocene & $\begin{array}{l}\text { Lile } \\
\text { (1978) }\end{array}$ \\
\hline $\begin{array}{l}\text { Camp } \\
\text { Century }\end{array}$ & $\begin{array}{r}(1966) \\
13-17\end{array}$ & 1377 & 5 & 0.2 & 4 & 6 & Basal, medium & $\begin{array}{l}\text { Present } \\
\text { work }\end{array}$ \\
\hline $\begin{array}{l}\text { Byrd } \\
\text { station } \\
\left(80^{\circ} 01^{\prime} s\right. \\
\left.19^{\circ} 31^{\prime} W\right)\end{array}$ & $\begin{array}{l}(1968 / 69) \\
4-8\end{array}$ & 1300 & $25-40$ & 4 & 4 & $2-3$ & $\begin{array}{l}\text { Wiscons in, } \\
\text { (tension) }\end{array}$ & $\begin{array}{l}\text { Shoji (un- } \\
\text { published) }\end{array}$ \\
\hline \multirow[t]{3}{*}{ Dye 3} & $\leqslant 0.1$ & $235-1293$ & $0.5-2$ & $0.5-2$ & 1 & 1 & $\begin{array}{l}\text { Holocene, } \\
\text { (compression) }\end{array}$ & $\begin{array}{l}\text { Shoji and } \\
\text { Langway } \\
\text { (1982[b]) }\end{array}$ \\
\hline & $\leqslant 0.5$ & 1814 & $8-10$ & 4 & 1 & $2-3$ & $\begin{array}{l}\text { Wiscons in, } \\
\text { (compression) }\end{array}$ & $\begin{array}{l}\text { Shoji and } \\
\text { Langway } \\
\text { (1982[b]) }\end{array}$ \\
\hline & $\leqslant 2$ & 2021 & 10 & 4 & 1 & 3 & $\begin{array}{l}16 \mathrm{~m} \text { above the } \\
\text { bottom, } \\
\text { (compression) }\end{array}$ & $\begin{array}{l}\text { Shoji and } \\
\text { Langway } \\
\text { (unpublished) }\end{array}$ \\
\hline $\begin{array}{l}\text { Mizuho } \\
\text { station } \\
\left(70^{\circ} 42^{\prime} \mathrm{S}\right. \\
\left.44^{\circ} 20^{\prime} \mathrm{E}\right)\end{array}$ & $\begin{array}{c}(1975) \\
2\end{array}$ & 100 & 1.2 & $1-2$ & 1 & 1 & $\begin{array}{l}\text { Holocene, } \\
\text { (compression) }\end{array}$ & $\begin{array}{l}\text { Shoj i } \\
(1978)\end{array}$ \\
\hline \multirow[t]{2}{*}{$\begin{array}{l}\text { Byrd } \\
\text { station }\end{array}$} & $\begin{array}{c}(1968 / 69) \\
4-8\end{array}$ & 300 & 6 & $1-1.5$ & 4 & 1 & $\begin{array}{l}\text { Holocene, } \\
\text { (tension) }\end{array}$ & $\begin{array}{l}\text { Shoj } i \\
\text { (unpubl ished) }\end{array}$ \\
\hline & & 1300 & $1-2$ & 0.1 & 4 & $3-5$ & $\begin{array}{l}\text { Wisconsin, } \\
\text { (tension) }\end{array}$ & \\
\hline $\begin{array}{l}\text { Dome } \\
\text { summit } \\
\left(67^{\circ} \mathrm{S} 113^{\circ} \mathrm{E}\right)\end{array}$ & (1969) & 318 & 1.41 & 1.47 & 1 & 1 & $\begin{array}{l}\text { Holocene, } \\
\text { (compression) }\end{array}$ & Lile (1978) \\
\hline $\begin{array}{l}\text { Dome C } \\
\left(74^{\circ} 39^{\prime} S\right. \\
\left.124^{\circ} 10^{\prime} \mathrm{E}\right)\end{array}$ & $\begin{array}{l}(1977 / 78) \\
\leqslant 3\end{array}$ & $?$ & 0.25 & 0.1 & 1 & 3 & $\stackrel{?}{\text { (compression) }}$ & $\begin{array}{l}\text { Duval and } \\
\text { Le Gac (1982) }\end{array}$ \\
\hline Dye 3 & $\leqslant 2$ & 1815 & $0.1-0.15$ & 0.1 & 1 & $1-2$ & $\begin{array}{l}\text { Wisconsin, } \\
\text { (compression) }\end{array}$ & $\begin{array}{l}\text { Shoji and } \\
\text { Langway (un- } \\
\text { published) }\end{array}$ \\
\hline
\end{tabular}


TABLE III. ESTIMATION OF ENHANCEMENT FACTOR (cont.)

Torsion, around vertical direction (easy glide)

\begin{tabular}{|c|c|c|c|c|c|c|c|c|}
\hline \multirow[t]{2}{*}{ Dome C } & $\begin{array}{c}(1977 / 78) \\
\leqslant 3\end{array}$ & 155 & 1.5 & $1-2$ & 1 & 1 & Holocene & $\begin{array}{l}\text { Duval and } \\
\text { Le Gac (1982) }\end{array}$ \\
\hline & & $?$ & 12.5 & 4 & 1 & 3 & $?$ & $\begin{array}{l}\text { Duval and } \\
\text { Le fac (1982) }\end{array}$ \\
\hline
\end{tabular}

Uniaxial compression, $45^{\circ}$ inclined under hydrostatic pressure (easy glide)

\begin{tabular}{|c|c|c|c|c|c|c|c|c|}
\hline $\begin{array}{l}\text { Byrd } \\
\text { station }\end{array}$ & $\begin{array}{c}(1968 / 69) \\
13\end{array}$ & 1400 & 8 & 4 & 1 & 2 & Wiscons in & $\begin{array}{l}\text { Azuma (un- } \\
\text { publ ished } \\
\text { report) }\end{array}$ \\
\hline \multirow[t]{3}{*}{ Dye 3} & $\begin{array}{c}(1980 / 81) \\
\leqslant 2\end{array}$ & 796 & $0.5-0.8$ & $0.5-1$ & 1 & 1 & Holocene & $\begin{array}{l}\text { Azuma and } \\
\text { Higashi } \\
\text { (unpublish- } \\
\text { ed report) }\end{array}$ \\
\hline & 1 & $800+1900$ & $4-8$ & 4 & 1 & $1-2$ & Wiscons in & $\begin{array}{l}\text { Azuma and } \\
\text { Higash } i \\
\text { (unpublish- } \\
\text { ed report) }\end{array}$ \\
\hline & & 2000 & $8-10$ & 4 & 1 & $2-3$ & $\begin{array}{l}37 \mathrm{~m} \text { above } \\
\text { the bottom }\end{array}$ & $\begin{array}{l}\text { Azuma and } \\
\text { Higashi } \\
\text { (unpub } 1 \text { ish- } \\
\text { ed report) }\end{array}$ \\
\hline
\end{tabular}

3 and 2 (clear and medium ices) have almost equal strain-rates, which are 40 to 100 times greater than those of laboratory prepared ice, and the type 1 specimens (dark ice) have about half the strain-rate of the other two types at the same stress level. We obtained a fabric enhancement factor of two for type 1 ice and four for type 2 and 3 ice using the diagram of Russe11-Head and Budd (1979). The strain-rate differences for the different types at the same stress level agrees quite well with those expected from the above fabric-factor diagram.

To investigate the hard-glide stress condition we tested another type 2 specimen with the stress direction $45^{\circ}$ from the horizontal plane. This test resulted in a strain-rate one order of magnitude lower than that obtained by the previous easy glide orientation (Fig.3). This result also agreed with the change of fabric enhancement factor both calculated and measured by Lile (1978). Since the concentration of debris particles is less than $0.7 \%$ by weight in every sample tested (Table I), the dispersion-hardening effect of particles should be small or negligible as indicated by the experiments of Hooke and others (1972). X-ray studies show that microstructures of both impuritydoped crystals (Oguro 1975) and relaxed ice-core samples (Shoj $i$ and Higashi 1978) have either mosaic patterns or sub-boundaries. Muguruma (1969) showed that the yield-stress of single ice-crystal specimens having sub-boundaries was as low as one quarter of those not having sub-boundaries. This softening is caused by the increase in mobile dislocation density. The softening effect created by HF doping is discussed in terms of dislocation mobility by Jones and Glen (1969).

The values of enhancement factors obtained in this work and other published data enable us to calculate horizontal velocity profiles and subsequently to discuss depth-age relationships.
4. APPLICATIONS TO GLACIER FLOW AND DISCUSSIONS 4 (a). Strain-rate enhancement factor

Fabric enhancement factors vary from one (random plot) to four (strong single maximum plot) depending upon preferred stress direction as related to basal glide direction (Lile 1978, Russell-Head and Budd 1979). In the case of hard glide deformation with a single fabric maximum, we estimate a fabric enhancement factor value of 0.1 based on our experimental data (Table III). For a highly relaxed ice core (considerable time after core recovery), we assigned a value of four to the ageing factor, based on experiments performed on fresh and relaxed ice cores (Shoj $i$ and Langway 1982[b], Shoj $i$ unpublished) and experiments made under confined and unconfined stress conditions (Azuma unpublished). For example, experimental results of the specimens taken from a depth of $300 \mathrm{~m} 4$ to 8 a after core recovery from Byrd station showed a measured enhancement factor of six in uniaxial tension tests, although the estimated fabric enhancement factor is between 1 and 1.5 (Table III). This "softening" is taken into consideration as an ageing factor resulting from the mosaic/sub-boundary structure formed during the volume relaxation process after core recovery. Table III gives a summary of unpublished experimental strain-rate data, together with measured total enhancement factors and estimated fabric/ageing enhancement factors. The remnant factor was def ined as measured enhancement factor divided by product of fabric factor and ageing factor. A remnant factor greater than one is closely related to Wisconsin ice or basal silty ice, as is shown in Table III. Experiments showed that certain types of impurities such as $\mathrm{HF}$ and $\mathrm{HCl}$ soften ice by increasing the mobility of a dislocation and/or by increasing the density of mobile dislocations (Jones and Glen 1969, Nakamura and Jones 1973). Chemical analyses made on polar ice cores reveal high $\mathrm{Cl}^{-}$contents in Wisconsin ice (Petit and 
others 1981 Herron [M M] and Langway 1982). Our results also show that basal silty ice at Camp Century includes a high content of soluble impurities, although the HF content of ice cores has not been measured and the effect of other impurities such as $\mathrm{SO}_{4}{ }^{2-}$ on the mechanical properties of ice is unknown. In this study we use the $\mathrm{Cl}^{-}$content as an impurity factor indicator, al though the measured concentration levels of $\mathrm{Cl}^{-}$seems to be too low to have a significant effect on the strain-rate enhancement. The $\mathrm{Cl}^{-}$ concentration in both Camp Century and Dye 3 ice cores increases with distance from the bottom, and is extremely high in ice of the late-Wiscons in period (Herron [M M] and Langway 1982). The highest $\mathrm{Cl}^{-}$level is found at locations at, or just beneath, the Holocene/Wiscons in transition, located at 232 and $251 \mathrm{~m}$ from the bottom at Camp Century and Dye 3, respectively. We assume an impurity enhancement factor of three for ice in which the $\mathrm{Cl}^{-}$concentration is greater than half of that in late-Wiscons in ice. The impurity enhancement factor elsewhere is unity, except for silty ice at Camp Century which has an impurity factor of three.

4(b). Horizontal velocity profile

The estimated enhancement factors as a function of depth-interval for the Camp Century and Dye 3 ice cores are given in Table IV. Strain-rates for these

TABLE IV. ESTIMATED ENHANCEMENT FACTORS FOR CALCULATING A VELOCITY PROFILE

Camp Century

$\begin{array}{lcccc}\begin{array}{l}\text { Depth } \\ \text { interval (m) }\end{array} & \begin{array}{c}\text { Fabric } \\ \text { factor }\end{array} & \begin{array}{c}\text { Impurity } \\ \text { factor }\end{array} & \begin{array}{c}\text { Total* } \\ \text { factor }\end{array} \\ & 0-500 & 1 & 1 & 1 \\ 500- & 900 & 2 & 1 & 2 \\ & 900-1155 & 3 & 1 & 3 \\ 1155-1267 & 4 & 3 & 12 \\ 1267-1 & 1370 & 3 & 1 & 3 \\ 1370-1387 & 4 & 3 & 12\end{array}$

Dye 3

$\begin{array}{rrr} & 0 & 0 \\ & 500-1 & 500 \\ 1 & 300=1 & 300 \\ 1 & 786-1 & 937 \\ 1 & 937-2 & 037\end{array}$

1
2
3
4
4

$\begin{array}{lr}1 & 1 \\ 1 & 2 \\ 1 & 3 \\ 3 & 12 \\ 1 & 4\end{array}$

*Total factor $=$ fabric factor $\mathrm{x}$ impurity factor

depth intervals were calculated using an empirical flow law obtained by Barnes and others (1971), and the enhancement factor mentioned above (assuming laminar flow). At Dye 3 , the surface slope is $3.3 \times 10^{-3} \mathrm{rad}$ (Overgaard and Gundestrup 1982) and the temperature profile in the bore hole has been measured by Gundestrup and Johnsen (1982). Fabric studies on the Dye 3 ice core were made by Herron [S L] and others (1982). The surface velocities calculated for Camp Century $\left(3.4 \mathrm{~m} \mathrm{a}^{-1}\right)$ and Dye $3\left(13.5 \mathrm{~m} \mathrm{a}^{-1}\right)$ agree quite well with the value of $3.3 \mathrm{~m} \mathrm{a}^{-1}$ measured at Camp Century and that of $12.3 \mathrm{~m} \mathrm{a}^{-1}$ at Dye 3

(N Gundestrup private communication). The velocity profiles obtained are shown in Figure 4 . The results obtained from borehole tilting measurements at Camp Century ( $B$ L Hansen private communication) are shown in Figure $4(\mathrm{a})$ for the bottom $300 \mathrm{~m}$. Hansen's results show a higher strain-rate at shallow depths than our calculation, and a value of $5.5 \mathrm{~m} \mathrm{a}^{-1}$ for surface velocity.

The horizontal velocity pattern calculated for Camp Century (Fig.4(a)) is quite similar to that calculated by Weertman (1968) except for two features: (1) the flow deformation of the ice sheet is highly concentrated with in the wiscons in depth interval, and

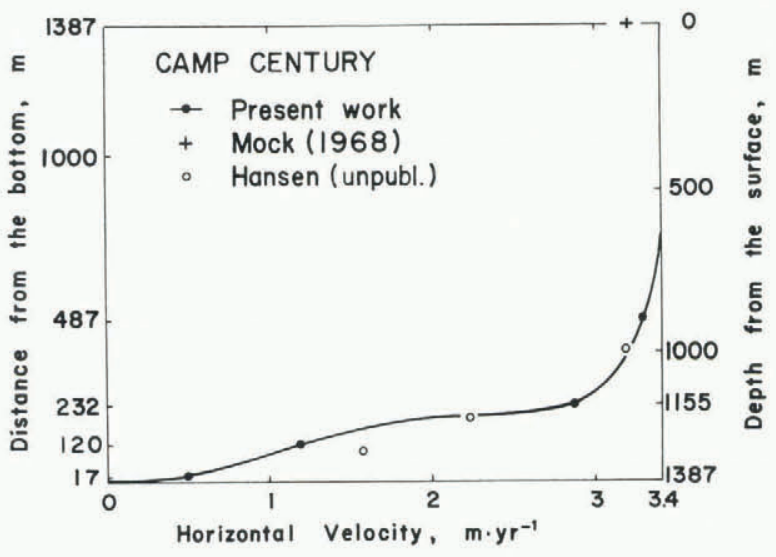

(a)

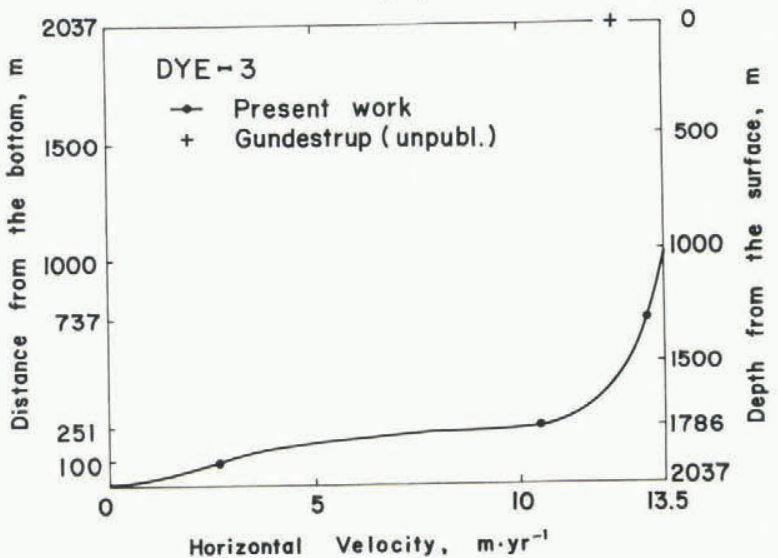

(b)

Fig.4. Smoothed horizontal velocity profiles calculated for Camp Century and Dye 3. Strain-rate calculations were made on each slab section at 10 to $100 \mathrm{~m}$ depth intervals (a greater spacing was used at shallow depths). Solid circles are calculated points at the depths for which the enhancement factor changes are deduced. Open circles shown in (a) were obtained from bore hole tilting measurements by $B$ L Hansen (private communication).

(2) the shear strain-rate decreases with depth for the lowest $125 \mathrm{~m}$. These same features are also shown in the calculated velocity pattern for Dye 3 (Fig. $4(\mathrm{~b})$.

$4(\mathrm{c})$. Depth-age profile

When calculating a depth-age relationship for the Camp Century core using the velocity profile obtained in this work, and assuming a two-dimensional steadystate flow as used by Dansgaard and Johnsen (1969), we obtain comparable results to time scale 1 . Our analys is shows that time scale 2 (Dansgaard and others 1982 ) is completely different from time scale 1 (calculated with ice-flow modeling of Dansgaard and Johnsen (1969)) for the bottom $250 \mathrm{~m}$ at Camp Century. The apparent discrepancy may result from variations in the horizontal velocity from those of the present day which occurred during the Wisconsin. The differences may be due to temperature, ice thickness, surface slope or enhancement factor differences, and accumulation rate was also probably different in the past. On the other hand, flow behavior can be estimated from time scale 2 itself. The time scale can be converted into an annual-layer thickness profile corresponding to the vertical velocity profile under a steadystate assumption. When a two-dimensional flow model is applied, the horizontal velocity pattern can be calculated from incompressibility conditions. This is an inverse procedure of the one used by Dansgaard and 


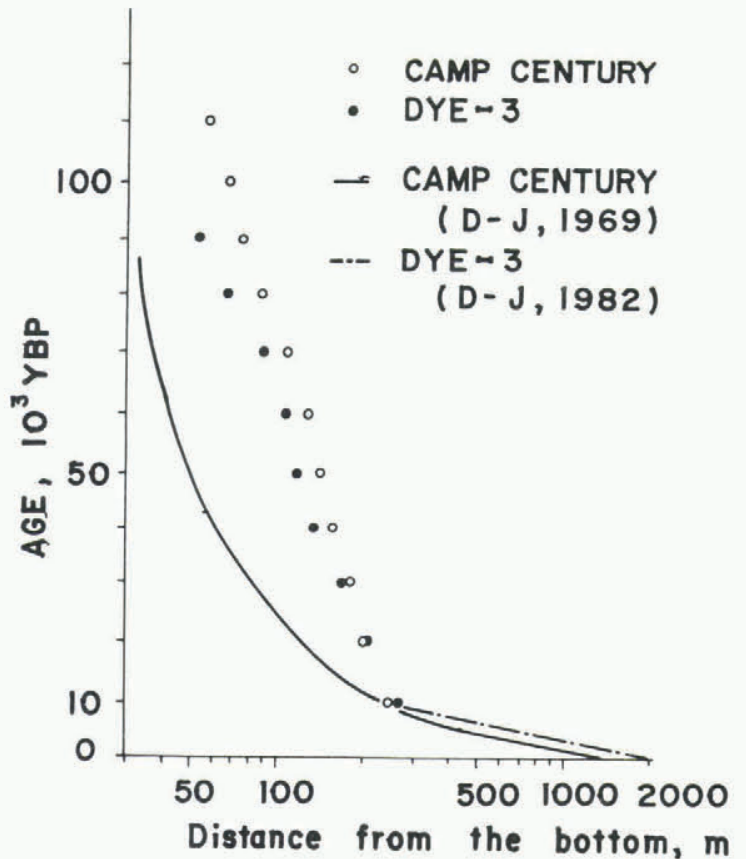

Fig.5. Depth-age profiles for Camp Century and Dye 3 . Open and solid circles (time scale 2) are obtained from $\delta^{18} 0$ measurements. Solid line for Camp Century (time scale 1) was obtained by Dansgaard and Johnsen (1969). Broken 1 ine for Dye 3 (time scale 1) was obtained with Dansgaard and Johnsen's model by Dansgaard and Reeh (1982).

Johnsen (1969) in which time scale 1 was calculated from the horizontal velocity pattern. It should be kept in mind, however, that additional hypotheses require additional assumptions. For these reasons, depth-age profiles for the Camp Century and Dye 3 ice cores have been plotted with $10 \mathrm{~g} / \mathrm{l}$ in axes on Figure 5. The depth-age profile so plotted gives a straight line when the vertical strain-rate is constant with depth. Time scale 2 for both the Camp Century and Dye 3 ice cores are apparently linear for the bottom $250 \mathrm{~m}$. Such a constant vertical strain-rate can be expected under a two-dimensional steady-state condition only when basal sliding is taking place. As discussed earlier, liquid lenses and veins were observed in type 1 (dark) ice in conjunction with debris particles which were incorporated from the base (Herron [S L] and Langway 1979). This indicates it is not only the pressure-melting mechanism which can cause basal melting. Another possibility arises when three-dimensional flow occurs, as would be expected from the large amplitude of the basal irregularities compared with the ice thickness observed along the Dye 3 flow line (Overgaard and Gundestrup 1982). A constant vertical strain-rate might be attained if the transversal strain-rate compensates the longitudinal strain-rate as required by an incompressibility condition under a steady-state assumption.

\section{ACKNOWLEDGMENTS}

Earlier discussions of theory with Dr J F Nye were instructive, and later discussions with Dr C U Hammer were very helpful. We thank Dr B L Hansen, Dr N Gundestrup, Dr A Higashi and Mr N Azuma for making available their unpublished data. This work was supported by the US National Science Foundation, Division of Polar Progams.

\section{REFERENCES}

Azuma N Unpublished Mechanical properties and textural change of Antarctic deep ice cores. (MS thes is, Hokkaido University, 1982)
Barnes P, Tabor D, Walker J C F 1971 The friction and creep of polycrystalline ice. Proceedings of the Royal Society of London Ser A 324(1557): 127-155

Dansgaard W, Johnsen S J 1969 A flow model and a time scale for the ice core from Camp Century, Greenland. Joumal of Glaciology 8(53): 215-223

Dansgaard W, Reeh N 1982 Cl imatic interpretation of GISP ice core data. Eos. Transactions, American Geophysical Union 63(18): 298

Dansgaard W, Johnsen S J, Møller J, Langway C C Jr 1969 One thousand centuries of climatic record from Camp Century on the Greenland ice sheet. Science 166(3903): 377-381

Dansgaard W and 6 others 1982 A new Greenland deep ice core. Science 218(4579): 1273-1277

Duvál P, Le Gac H 1982 Mechanical behaviour of Antarctic ice. Annals of Glaciology 3: 92-95

Glen J W 1955 The creep of polycrystalline ice. Proceedings of the Royal Society of London Ser A 228(1175): 519-538

Gundestrup N, Johnsen S J 1982 A battery powered, instrumented deep ice core drill for liquid filled holes. Eos. Transactions, Ame rican Geophysical Union 63(18): 297

Hammer C U 1977[a] Dating of Greenland ice cores by microparticle concentration analyses. Inter national Association of Hydrological Sciences Publication 118 (General Assembly of Grenoble 1975 Isotopes and Impurities in Snow and Ice): 297-301

Hammer C U 1977[b] Dust studies on Greenland ice cores. Intermational Association of Hydrological Sciences Publication 118 (General Assembly of Grenoble 1975 - Isotopes and Impurities in Snow and Ice): $365-370$

Hammer C U, Clausen H B, Dansgaard W, Gundestrup N, Johnsen S J, Reeh N 1978 Dating of Greenland ice cores by flow models, isotopes, volcanic debris, and continental dust. Joumal of Glaciology 20(82): 3-26

Hansen B L, Langway C C Jr 1966 Deep core drilling in ice and core analys is at Camp Century, Greenland 1961-1966. Antarctic Journal of the United States $1(5)$ : $207-208$

Hays J D, Imbrie J, Shackleton N J 1976 Variations in the Earth's orbit: pacemaker of the ice ages. Science 194(4270): 1121-1132

Herron M M, Langway C C Jr 1982 Chloride, nitrate and sulfate in the Dye 3 and Camp Century, Greenland ice cores. Eos. Transactions, American Geophysical Union 63(18): 298

Herron S L, Langway C C Jr 1979 The debris-laden ice at the bottom of the Greenland ice sheet. Jourmal of Glaciology 23(89): 193-207

Herron S L, Langway C C Jr 1982 A comparison of ice fabrics and textures at Camp Century, Greenland and Byrd station, Antarctica. Annals of Glaciology 3: $118-124$

Herron S L, Langway C C Jr, Brugger K A 1982 U1trasonic velocities and crystalline anisotropy in the ice core from Dye 3, Greenland. Eos. Transactions, American Geophysical Union 63(18): 297

Higuchi K 1958 The etching of ice crystals. Acta Metallurgica 6(10): 636-642

Hooke R L, Dahl in B B, Kauper M T 1972 Creep of ice containing dispersed fine sand. Joumal of Glacio$\log _{y} 11(63)$ : $327-336$

Jones S J, Glen J W 1969 The effect of dissolved impurities on the mechanical properties of ice crystals. Philosophical Magazine 19(157): 13-24

Langway C C Jr 1958 Bubble pressures in Greenland glacier ice. Intermational Association of Scientific Hydrology Publication 47 (Sympos ium of Chamonix - Physics of the Motion of Ice): 336-349

Lile R C 1978 The effect of anisotropy on the creep of polycrystalline ice. Joumal of Glaciology 21 (85): $475-483$

Matsuda M 1979 Determination of $\alpha$-axis orientations of polycrystalline ice. Joumal of Glaciology 22(86): 165-169 
Miller S L 1969 Clathrate hydrates of air in Antarctic ice. Science 165(3892): 489-490

Mock S J 1968 Snow accumulation studies on the Thule peninsula, Greenland. CRREL Research Report 238

Muguruma J 1969 Effects of surface condition on the mechanical properties of ice crystals. British Joumal of Applied Physice 2(11): 1517-1525

Nakamura T, Jones S J 1973 Mechanical properties of impure ice crystals. In Whalley $\mathrm{E}$, Jones $\mathrm{S} \mathrm{J}$, Gold L W (eds) Physics and chemistry of ice. Papers presented at the Symposium on the physics and chemistry of ice held in Ottawa, Canada, 14-18 August, 1972. Ottawa, Royal Society of Canada: 365-369

Nye J F 1957 The distribution of stress and velocity in glaciers and ice-sheets. Proceedings of the Royal Society of London Ser A 239(1216): $113-133$

Oguro M 1975 Growth of ice single crystals from dilute aqueous solutions by the modified Bridgmena method - distribution of impurities and structure of dislocations. Hokkaido University. Faculty of Engineering. Bulletin 74: 83-94

Overgaard S, Gundestrup N 1982 Influence of upstream topography on the Dye 3 core. Eos. Transactions, American Geophysical Union 63(18): 297-298

Petit J-R, Briat M, Royer A 1981 Ice-age aerosol content from East Antarctic ice core samples and past wind strength. Nature 293(5831): 391-394

Russell-Head D S, Budd W F 1979 Ice-sheet flow properties derived from bore-hole shear measurements combined with ice-core studies. Joumal of Glaciology 24(90): 117-130

ShojiH 1978 Stress-strain tests of ice core drilled at Mizuho station, East Antarctica. National Institute of Polar Research. Memoirs. Special Issue 10: 95-101

Shoji H Unpublished Solid state physics study of Antarctic deep core ice. (Ph D thes is, Hokkaido University, 1978)

Shoji H, Higashi A 1978 X-ray diffraction topographic studies of Antarctic deep core ice. Japanese Joumal of Applied Physics 17(6): 993-1001

Shoj i H, Langway C C Jr 1982[a] Air hydrate inclusions in fresh ice core. Nature 298(5874): 548-550

Shoji H, Langway C C Jr 1982[b] Mechanical property of fresh ice core from Dye 3, Greenland. Eos. Transactions, American Geophysical Union 63(18): 297

Shoji H, Langway C C Jr 1983 Volume relaxation of air inclusions in fresh ice core. Joumal of Physical Chemistmy 87(21): 4111-4114

Weertman J 1968 Comparison between measured and theoretical temperature profiles of the Camp Century, Greenland, borehole. Joumal of Geophysical Research $73(8)$ : $2691-2700$ 